Kafkas Üniversitesi Sosyal Bilimler Enstitüsü Dergisi

Kafkas University Journal of the Institute of Social Sciences

Sayı Number 17, Bahar Spring 2016, 127-138

DOI:10.9775/kausbed.2016.007

Gönderim Tarihi: 15.01.2016

Kabul Tarihi:25.06.2016

DÂVÛD-İ KARŜ̂'NİN “EL-İSAGOCi CEDİD VE'DDÜRRU'L-FERÎD” ADLI MANTIK RISÂLESII: TANITIM VE TENKITLLI NEŞIR

The Critical Edition of Treatise on Logic Entitled “Al-İsagoci Cedid ve'd-Dürru'l-Ferîd” Written by Dâvûd-i Karsî

$\ddot{O} z$

Ruhattin YAZOĞLU

Prof. Dr., Atatürk Üniversitesi

İlahiyat Fakültesi

Felsefe ve Din Bilimleri Bölümü

Din Felsefesi Ana Bilim Dalı

ryazoglu@atauni.edu.tr

Bünyamin ÇALIK

Yrd. Doç. Dr., Kafkas Üniversitesi

İlahiyat Fakültesi

Temel İslam Bilimleri Bölümü

İslam Hukuku Ana Bilim Dalı

buncalik@hotmail.com

Çalıșmanın Türü: Araştırma

Bu makale, mantık alanıyla yapacă̆ımız tahkik çalışmamızın ikincisini oluşturmaktadır. Makalenin ilk kısmında risâlenin müellifi Dâvûd-i Karsî'nin hayatı ve eserlerini, risâlenin (varsa) nüshalarını ve tanıtımlarını, risâlenin yazllı̧̧ gayesini ve içeriğini ele aldık. Daha sonra tahkikteki metodumuzu sunduk. Sonunda ise risâlenin tenkitli neşrini verdik.

Anahtar Kelimeler: Önerme, klyas, İsagoci, el-Karsî

Abstract

This article is intended to be the second verification article that we are aiming to do in the area of logic. In the first part of the article, we focused on life and works of the author Dâvûd-i Karsî and the evaluation of various copies of the Treatise and introductions from other authors along with the purpose of writing and the content. We then presented the verification methodology that we used. In the last part, we presented the entire publication along with our critics.

Key Words: Preposition, syllogism, İsagoci, al-Karsî

\title{
Giriş
}

Mantık, ak1l yürütmeyi konu edinmenin yanında, yapılan akıl yürütmenin geçerliliğini de amaç edinir. Çünkü mantıkta, akıl yürütmenin geçerli olması ve sonucun öncüllerden zorunlu bir biçimde çıkması esastır. Bu durum mantığın amacını ortaya koyar. Mantık, amacına göre "kurallarına uyulduğunda zihni hataya düşmekten koruyan bir fen, bir sanattır" şeklinde tanımlanır. Konusu ve amacına göre yaptığımız bu tanımlar, mantığın, doğru 
ve geçerli akıl yürütmeyi öğreten, zihni yanlış yapmaktan alıkoyan hem ilim hem de sanat olduğunu gösterir. ${ }^{1}$

Her ne kadar Çin, Hint ve Yunan'daki filozoflar, mantık üzerinde çeşitli düşünceler ileri sürmüşlerse de, bu bilimi ilk defa sistemli bir şekilde ele alan ve disiplin haline getiren Aristoteles (M.Ö.384-322) olmuştur.

Ortaçağ İslâm dünyası, Aristoteles felsefesi ve mantığıyla VIII. yüzyılın başlarından itibaren Müslümanların fethettikleri Suriye ve civarında karşılaştı. Mantık eserlerinin tercümesi ise, yine VIII. yüzyıldan itibaren başlar. IX. yüzyılın ortalarından itibaren de felsefî sahada olduğu gibi, mantık alanında da birçok eser telif edilmiştir. ${ }^{2}$

Burada hemen şunu da belirtelim ki Müslümanlar, mantığı yalnızca kendi dillerine tercüme ettirmekle kalmadılar aynı zamanda onu yorumlayarak ve kendilerine dönüştürüp görüşlerini de ekleyerek, birtakım değişiklikler yapmışlardır. Ancak bu değişiklikler sadece İslâm mantıkçılarının yaptığı değişiklikler olmayıp, Aristoteles'ten sonra başlamış ve mantığın İslâm düşüncesine nakledilmesiyle birlikte devam etmiş olan değişikliklerdir. Söz konusu değişiklikler, mantık ilminin dil ile ilişkilendirilmesi, şartlı önermeler, modalite konusu, kategorilerin mantık ilminden çıkarılması ve mantığın başta Aristoteles metafiziği olmak üzere çeşitli metafizik düşüncelerden arındırılarak formel bir ilim halini alması gibi değişikliklerdir. ${ }^{3}$

İslâm düşüncesinde mantık, Gazâlı̂’nin gayretleri sonucu, bütün Müslümanlar tarafından büyük bir rağbet görmüş ve medreselerde en temel derslerden biri haline gelmiştir. Gazâlî'den sonra Râzî, İbn Rüşd, Ebherî, Kazvinî, Urmevî, Kutbeddin Şirazî, Taftazanî, Cürcanî, sonraki dönemlerin büyük mantıkçılarındandır.

Osmanlı'da Tanzimat'tan sonra Dâvûd-i Karsî’nin el-İsagoci Cedid ve'd-Dürru'l-Ferîd, Risâle fíl-Istılahati'l-Mantıkiye, Şerhü Takrîri'lKavânini'l-Mütedavile fî İlmi'l-Münâzâra, Şerhü Tekmîle mine'l-Mantık ve'lÂdâb ve Şerhü Tekmîleti't-Tehzîb fíl-Mantık'1, Ahmet Cevdet Paşa'nın Mi'yar-ı Sedat'1, Ali Sedat'ın Mizanu'l-Ukûl fi'l-Mantık ve'l-Usûl'ü ile İzmirli İsmail Hakkı'nın Felsefe Dersleri'nde mündemiç olan mantık ve Fenn-i Menahic vb. eserleri kaleme alınmıştır.

${ }^{1}$ HASIRCI, N. 2010: İbn Teymiyye'nin Mantık Eleștirisi, 9-10, Ankara.

${ }^{2}$ YAZOĞLU, R., İMAMOĞLU, T. 2012: Klasik Mantık, Rağbet Yayınları, 23, İstanbul.

${ }^{3}$ AYIK, H, 2007: İslâm Mantık Geleneği ve Doğuluların Mantığı, 18, İstanbul. 


\section{Risâle'nin Tanıtımı}

\subsection{Risâlenin Müellifi: Hayatı ve Eserleri}

Aslen Karslı olup doğum tarihi ve ailesi hakkında kesin bilgi bulunmamaktadır. Döneminde Dâvûd-i Karsî veya Dâvud Efendi (ö. 1169/1756) olarak tanınmıştır. Sonraları Kara Dâvud diye anılmışsa da bu kendisinden çok önce yaşamış olan Taftâzâni'nin talebesi Kara Dâvud veya Dâvud b. Kemâl el-Kocevî el-İzmitî ile (948/1541) karıştırılmış olmasından kaynaklanmaktadır. Bütün eserlerinin mukaddimesinde kendisini Dâvud b. Muhammed el-Karsî el-Hanefî̀ şeklinde tanıtan Dâvûd-i Karsî, temel medrese eğitimini Kars'ta o yörenin tanınmış zâhid ve âlimi Çolak Abdullah Efendi'den yaptı. Daha sonra İstanbul'a giderek tahsilini ve mülâzemetini tamamladi.

Akkirmâni'nin de mümeyyiz olarak bulunduğu ruûs imtihanında başarılı oldu. Bu imtihanda mümeyyizlerin kendisine sorduğu sorularla onun verdiği cevaplardan oluşan Risâletü'l-imtihan'ı Süleymaniye Kütüphanesi'nde bulunmaktadır. Osmanlı ilmiye geleneğine göre ruûs imtihanında başarılı olanlar taşra medreselerinden birine müderris olarak tayin edilirlerse de kaynaklarda Dâvûd-i Karsî hakkında bu hususla ilgili bir bilginin bulunmamasından ve resmî makamlardan uzak kalarak zâhidâne bir hayat yaşamış olmasından hareketle onun böyle bir tayine yanaşmadığı sonucunu çıkarmak mümkündür. Her ne kadar başta Âkifzâde el-Amâsî olmak üzere Dâvûd-i Karsî'den bahseden bütün kaynaklar, onun mülâzemetini tamamladıktan sonra Birgi'ye gittiğini kaydediyorsa da eserleri yazıldıkları yer ve tarihlere göre incelendiğinde Dâvûd-i Karsî'nin tahsilini tamamladıktan sonra Mısır'a gittiği, orada kısa bir süre içinde ilmî ehliyetini çevresine kabul ettirip ders vermeye başladığı ve daha ziyade öğrencilerinin ihtiyacı doğrultusunda eserler telif ettiği anlaşılır. Dâvûd-i Karsî'nin Misır'dan ne zaman döndüğü kesin olarak belli değildir. Ancak Misır'da iken telif ettiği bilinen eserlerinden ikisinin öğrencileri tarafından 1154 yılının ilk aylarında (1174'in ortaları) İstanbul'da istinsah edilmiş olmasını dikkate alarak 1153 yılının sonlarında (1174'in ilk ayları) İstanbul'a geldiğini söylemek mümkündür. Dâvûd-i Karsî bir süre sonra kendisine hayran olduğu ünlü Türk bilgini Birgivî’nin memleketi olan Birgi kasabasına giderek orada yerleşmiş ve Birgi Ulu Camii Medresesi'nde müderrislik yapmıştır. Daha sonra 1159/1746 yılında Kıbrıs'a gittiği, bir müddet orada kalarak öğretim ve irşat faaliyetiyle meşgul olduğu, bu sırada kaleme aldığı bilinen eserlerinden anlaşılmaktadır. 1162 yılının Ramazan bayramında bir ziyaret amaciyla Lârende'de/Karaman bulunduğu, orada yazdığ ferağ kaydından öğrenilmektedir. Hayatının son on beş yılını Birgi'de geçiren Dâvûd-i Karsî 1169 yılının son günlerinde bu kasabada vefat etti. 
Vasiyeti gereği Birgi'nin dişındaki bir tepe üzerinde medfun bulunan Birgivi'nin yanına gömüldü. Dâvûd-i Karsî'nin Ömer ve Osman adlı iki oğlunun bulunduğu, bunların eserlerinden bahseden bazı kaynaklardan öğrenilmektedir. ${ }^{4}$

El-Karsî'nin tanıtım ve tenkitli neşrini yaptığımız bu mantık risâlesi ve diğer bütün risâleleri, müellifin kendi hattıyla kaleme alınmıştır. $\mathrm{Bu}$ verilere dayanarak müellifin çalışmalarını/eserlerini şöyle sıralayabiliriz:

1. Amentü Şerhi

2. Cevâhiru'l-Maziye fî Tabakâti'l-Hanefîye

3. el-İhtiyaratü'l-Cüziye ve'l-İradatü'l-Kalbiye

4. el-İsagoci Cedid ve'd-Dürru'l-Ferîd

5. el-Mev'ize

6. er-Risâletü'l-Fethîye fî̀l-A'mâli'l-Ceybiye

7. er-Risâletü'l-Mürşide

8. Fususü'l-Hikem Şerhi

9. Hâşiye alâ Şerhi Tehzîbi'l-Mantık ve'l-Kelâm

10. İlm-i Hâl

11. Mâlumât-1 Dinîye

12. Mecmû'a-i Eş'âr

13. Miftâhu'l-Fâtiha

14. Mukaddimetu'l-İslâm

15. Risâle fî Beyâni Sifâtillahi Taalâ Sifat-İlâhiye

16. Risâle fî̀ Hakki Sifâtillahi İnde'l-Maturidiye

17. Risâle fî Tafsîli ma Hasale mine's-Su'al ve'l-Cevâb fî'l-İmtihân

18. Risâle fî Unani'l-İ́cmal ve't-Tafsîl

19. Risâle fîl'-Istılahati'l-Mantıkiye

20. Risâle fî't-Ta'rifât

21. Risâle fî't-Tarîkati'n-Nakşibendîye

22. Risâle-i Adâb-i Bahs

23. Risâletü'l-Fethîye

24. Suverü'l-Kur'an

25. Şerh-i Risâle-i Birgivî

26. Şerh-i Tarîkatü'l-Muhammediye

27. Şerhu 'alâ Usûli'l-Hadîsi'l-Birgivî

28. Şerhu Aruzü'l-Endülüsi

29. Şerhü Avâmili'l-Cedîde

30. Şerhü Cedid ala'ş-Şemsiye

4 AKPINAR, C. 1994: “Dâvûd-i Karsî”, Türkiye Diyanet Vakfı İslâm Ansiklopedisi, IX/29, İstanbul. 


\author{
31. Şerhü Dürri'l-Yetîm \\ 32. Șerhü Kasîdeti Yekûlü'l-Abd Șerhü Kasîdeti Yekûlü'l-Abd \\ 33. Şerhü Kasîdeti'n-Nûniye \\ 34. Şerhü Mes'eleti'l-İhtiyarat \\ 35. Şerhü Risâle fî Rub'i'l-Mukantarât \\ 36. Şerhü Risâle fî'l-İmân ve'd-dîn \\ 37. Şerhü Takrîri'l-Kavânini'l-Mütedavile fî İlmi'l-Münâzâra \\ 38. Şerhü Tekmîle mine'l-Mantık ve'l-Âdâb \\ 39. Şerhü Tekmileti'l-Hadiye \\ 40. Serhü Tekmîleti't-Tehzîb fî'l-Mantık \\ 41. Şerhü Usûli'l-Hadîs \\ 42. Şerhü'l-Besmele \\ 43. Serhü'1-Emsileti'l-Muhtelife \\ 44. Şerhü'l-İzhâri'l-Esrâr \\ 45. Serhü'l-Kasîdeti'l-Hamrîye \\ 46. Şerhü'r-Risâleti'ş-Şemsîye fî'l-Kavâ'idi'l-Mantıkiye \\ 47. Tekmilet el Tehzib fi el-Mantık \\ 48. Tekmîletü't-Tehzîb fî'l-Mantık \\ 49. Telhîs-i Takrîrü'l-Kavanin
}

\title{
1.2. Risâlenin Nüshaları, Tavsifleri ve Karşılaştırılması
}

Araştırmamız neticesinde risâle'nin bir nüshasını tespit ettik. İsmi de el-İsagoci Cedid ve'd-Dürru'l-Ferîd'dir. Millî Kütüphane kayıtlarında geçmektedir. ${ }^{5}$ Dâvûd-i Karsî’nin ilgili risâlesinin ismi, yazma metinde geçmekte ve metin besmele ile başlamaktadır. Bu nüshayı, çalışmamızın esas nüshas1 olarak belirledik; dipnotlarda el-İsagoci Cedid ve'd-Dürru'lFerîd olarak gösterdik.

İlgili nüsha, 7 varaktan oluşmaktadır. Eser yazar tarafından kaleme alınmıştır. Metin, rik'a el yazısı hattıyla yazılmış olup okunaklı ve nettir.

Varakların numaralandırılması müellif tarafından yapılmamış, sonradan diğer risâlelere istinaden "1a'dan başlayarak 7b"de bitirilmiştir. İlk varakın (1a) sayfası kısa bir dua ile başlamıştır. Yazmanın Millı̂ Kütüphane nr. 06-Hk-3212-1 vr. 0002-0009 kaydı da vardır. 1. varakın ilk sayfasında (1a), başta bir besmeleden sonra metin yer almaktadır. Satır sayısı, 21 'dir. 1 . varakın ikinci sayfası (1b)'nda 22 satır vardır. 2. varakın ilk sayfası (2a), ikinci sayfası (2b) ve 3. varakın ilk sayfası (3a)'nda 23 satır bulunmaktadır. 3. varakın ikinci sayfası (3b) ve 4 . varakın ilk sayfası (4a)'nda 24 satır vardır. 4. varakın ikinci sayfası (4b), 5. varakın ilk sayfası (5a) ve ikinci

${ }^{5}$ Millî Ktp., Esat Efendi, nr. 06-Hk-3212-1 vr. 0002-0009. 
sayfas1 (5b), 6. varakın ilk sayfası (6a) ve ikinci sayfası (6b)'nda 23 satır bulunmaktadır. 7. varak (7a)'ın satır sayıs1 ise 19'dur.

Metnin diline gelince, mukaddime bölümünde secili bir düzyazı tercih edilmekle beraber asıl metin bölümünde secisiz bilimsel bir nesir/ifade kullanılmıştır. Eserin ana metnindeki bilgilerin nereden alındığına dair bazen bir açıklama ve işaret bulunmaktadır.

Dâvûd-i Karsî'nin bu mantık risâlesinin diğer mantık risâleleri arasındaki yerini de şu şekilde belirtebiliriz: Bilindiği gibi Ebherî'nin İsagoci'si, Kâtibi'nin Şemsiyye'si, Urmevî'nin Metâliu'l-Envar'ının mantık kısmı ve Taftazanî'nin Tehzibu'l-Mantık isimli eseri, hiç kuşkusuz 13. ve 14. yüzyıl sonrası İslâm mantık çalışmalarının mihverini teşkil etmiş, meşhur şerh ve haşiyeleriyle zengin bir literatürün oluşmasına kaynaklık etmiş temel eserlerdir. $\mathrm{Bu}$ eserler arasından oluşturmuş olduğu şerh geleneğiyle yaygınlık ve etkisi bakımından en başta geleni, Ebherî'nin İsagoci'sidir. İsagoci şerh geleneği içinde de Talişi haşiyesiyle birlikte Hüsam Katî şerhi ve Kul Ahmet haşiyesiyle birlikte Molla Fenari şerhi iki büyük alt gelenek oluşturmuştur. Bu büyük mantık geleneği içinde Dâvûd-i Karsî’nin İsagoci şerhinin, ifade gücü ve sadeliğiyle sözü edilen meşhur şarihler karşısında önemli bir yer edindiği görülmektedir.

\subsection{Risâlenin Yazılış Gayesi}

Müellif mantıklı düşünmenin düzenli olarak tespit edilebilmesi için, Mantık ilminin zorunlu olduğunu dile getirmiştir. Zira ona göre mantık, zihni hatadan koruyan bir fen, bir alettir. Mantık, doğru düşünmeyi öğreten ve hakikati bulma kurallarını ortaya koyan bir bilimdir. Yine, mantık, şeylerin bilgisinde aklını iyi kullanma sanatıdır.

\subsection{Risâlenin Tanıtımı ve Muhtevası}

Metnin iskeletine bakacak olursak, besmele, hamdele ve salveleden sonra bu risâlenin neleri konu edindiği ve neyi hedeflediği açıklanmıştır. ${ }^{6}$ Müellif risâlede mantık'ın tanımıyla konuya giriş yapmış, daha sonra diğer mantık konularını ele almış ve ders işleme adâbı ile risâleyi bitirmiştir. ${ }^{7}$

\subsection{Risâlenin Tenkidi}

Klasik mantığın konularını; kavramlar mantığı, önermeler mantığ1, kıyas, tasdik türleri ve beş sanat oluşturmaktadır. Dâvûd-i Karsî de elÍsagoci Cedid ve'd-Dürru'l-Ferîd adlı mantık risâlesinde, klasik mantığın bu

${ }^{6}$ DÂVÛD-I KARSÎ, el-İ́sagoci Cedid ve'd-Dürru'l-Ferîd, vr. 1a.

${ }^{7}$ DÂVÛD-I KARSÎ, el-İsagoci Cedid ve'd-Dürru'l-Ferîd, vr. 7a. 
konularına yer vermiştir. Ayrıca Karsî, bu risâlenin sonunda, günümüz klasik mantık kitaplarında pek rastlamadığımız "ders işleme adâbı" şeklinde bir konuya da temas etmiştir.

Ebherî’nin İsagoci metninden bağımsız bir şekilde mantıkla ilgili özgün görüşlerini ve tercihlerini ifade ettiği eserinde Karsî'nin mantığa genel yaklaşımı, dinî ilimlere hizmet açısından mantık ilmiyle meşgul olma yönündedir. Dolayısıyla bu sınırı aşan spekülatif "felsefî mantık" çalışmalarına sıcak bakmayan Dâvûd-i Karsî, bu bağlamda meşhur mantık eserleri ve mantıkçılara da bazı eleştiriler getirerek özgün bir yaklaşım ortaya koymuş bir âlim olarak öne çıkmaktadır.

Bütün bu nedenlerden dolayı, mantığa ihtiyaç duyanlar için bu risâle faydalı olacaktır.

\section{KAYNAKLAR}

AKPINAR, C. 1994: “Dâvûd-i Karsî”, Türkiye Diyanet Vakfı İslâm Ansiklopedisi, IX/29, İstanbul.

AYIK, H, 2007: İslâm Mantık Geleneği ve Doğuluların Mantı̆̆ı, 18, İstanbul.

DÂVÛD-I KARSî, el-İsagoci Cedid ve'd-Dürru'l-Ferîd, vr. 1a.

HASIRCI, N. 2010: İbn Teymiyye'nin Mantık Eleştirisi, 9-10, Ankara.

MİLLÎ KTP., Esat Efendi, nr. 06-Hk-3212-1 vr. 0002-0009.

YAZOĞLU, R.-IMAMOĞLU, T. 2012: Klasik Mantık, Rağbet Yayınları, 23, İstanbul.

\section{METIN}

$$
\begin{aligned}
& \text { بسم الله الرحمن الرحيم }
\end{aligned}
$$

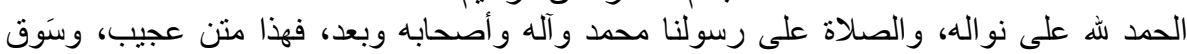

$$
\begin{aligned}
& \text { غريب جعلته تبصرة لكل لبيب وسميته بالإيساغوجي الجديد وبالدر الفريد، والله ولي التوفيق، وبيده وستيد } \\
& \text { ازمّة التحقيق. }
\end{aligned}
$$

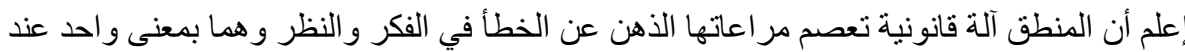

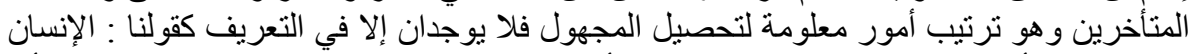

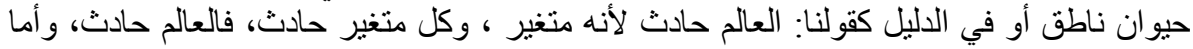

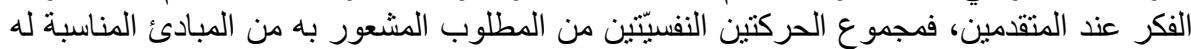

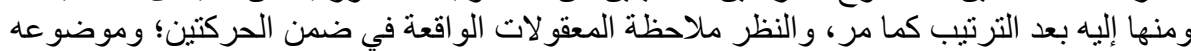

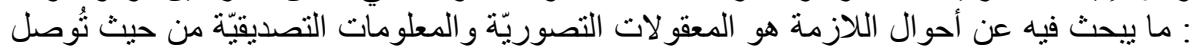

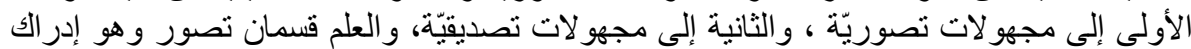

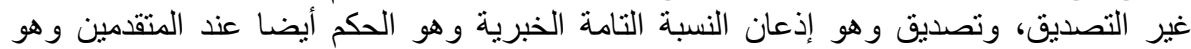

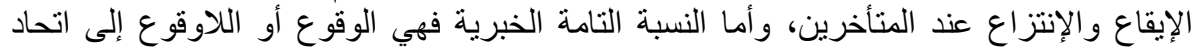

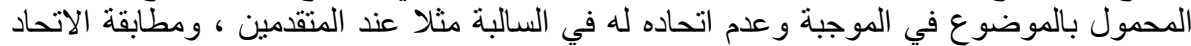

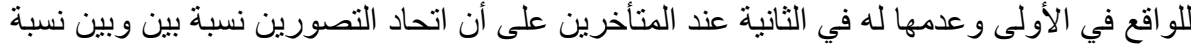

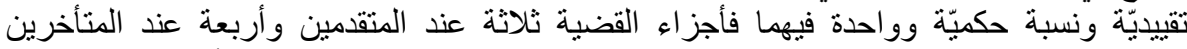

$$
\begin{aligned}
& \text { وغرضه إلى الغرض منه الباعث على تحصيله (1a) عصمة الذهن عن الخطأ فيهما ولذا قالوا: }
\end{aligned}
$$




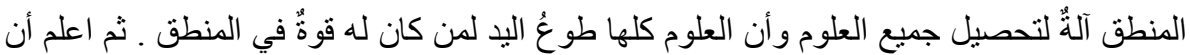

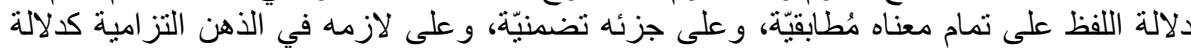

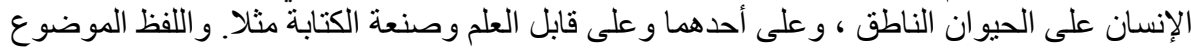

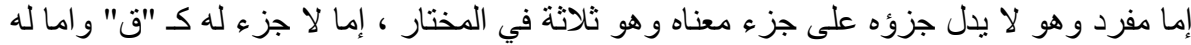

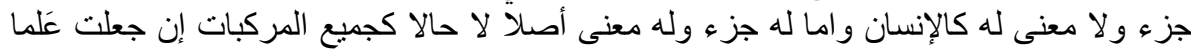

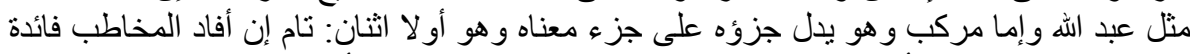

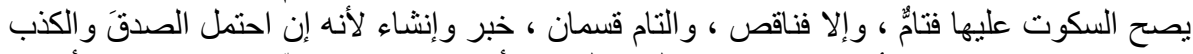

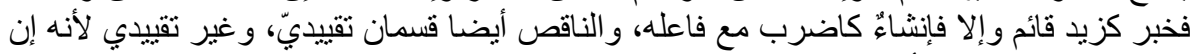

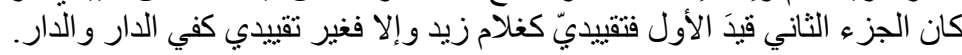

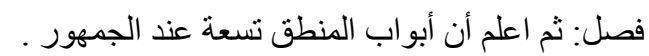

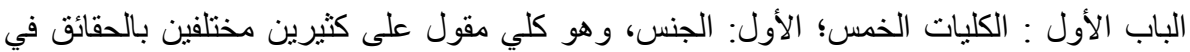

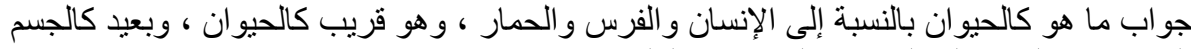

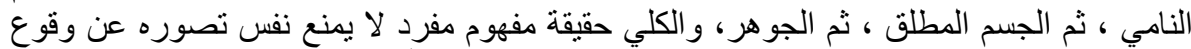

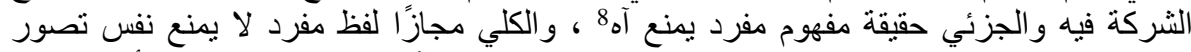

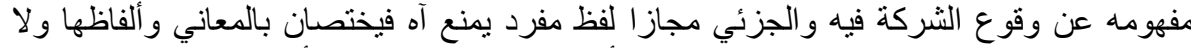

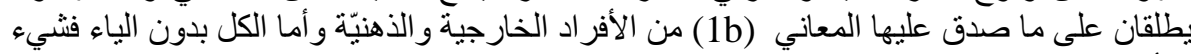

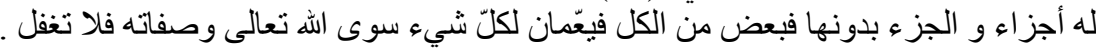

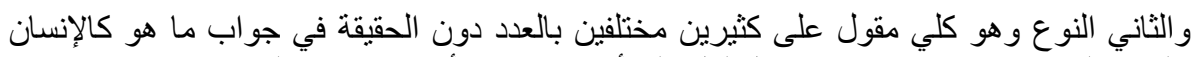

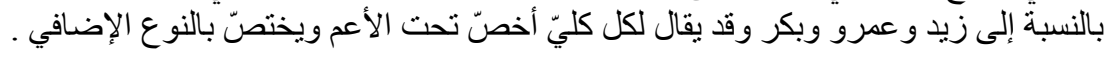

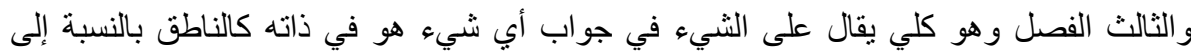

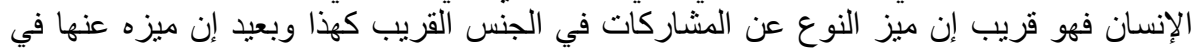

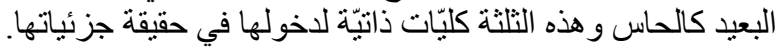

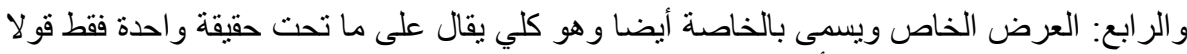
عرضيّا كالضاحك بالنسبة إلى أفر اد إلانسان .

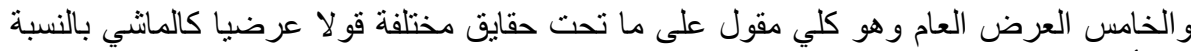

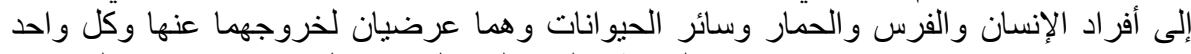

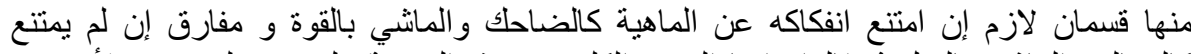

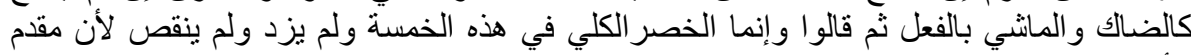

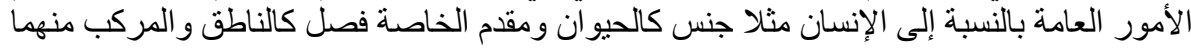

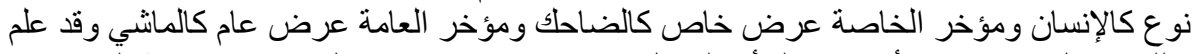

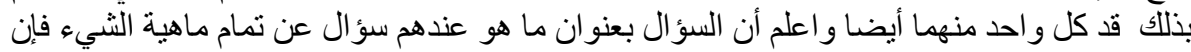

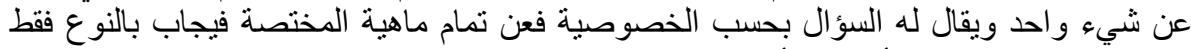

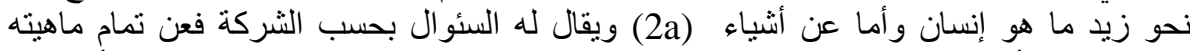

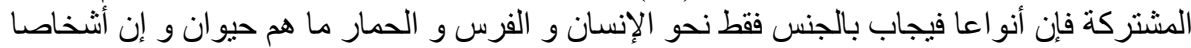

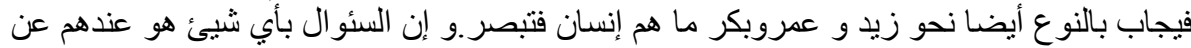

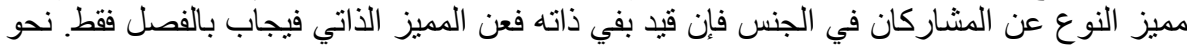

8 "أه" يعني: إلى آخره،؛الجزئي: حقيقة دفهوم دفرد يمنع نفس تصوره عن وقوع الثركة فيه. 


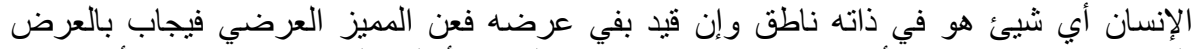

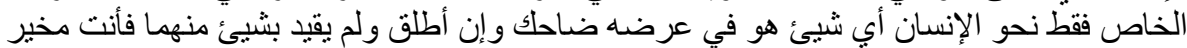

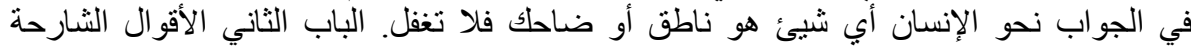

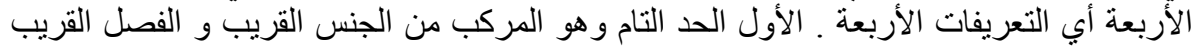

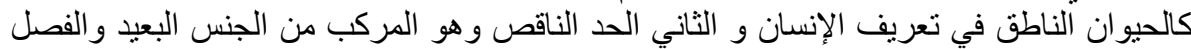

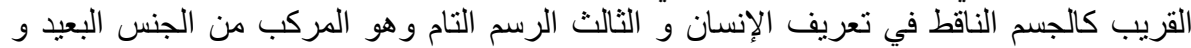

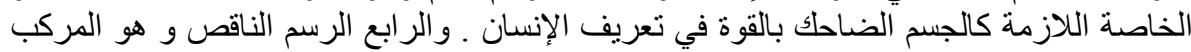

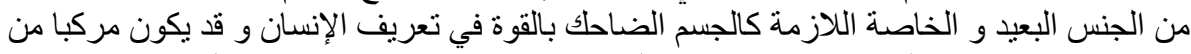

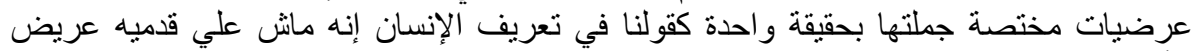

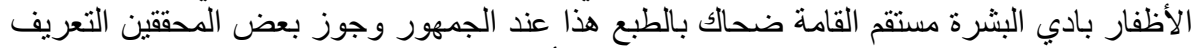

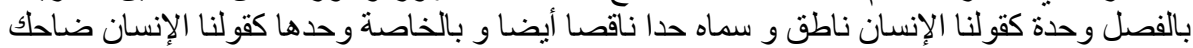

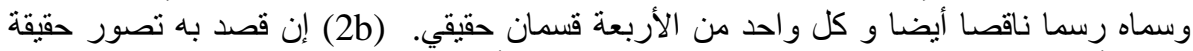

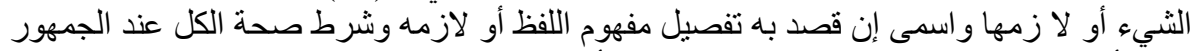

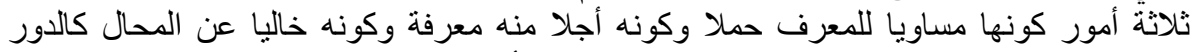

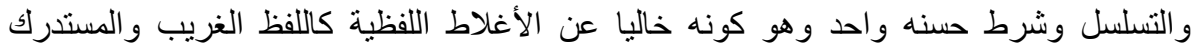

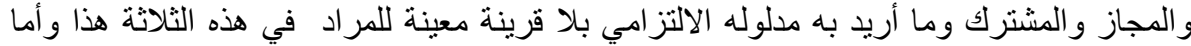

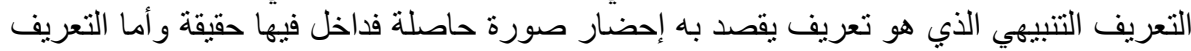

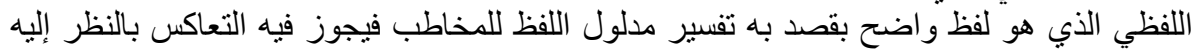

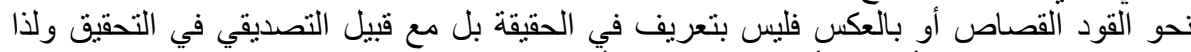

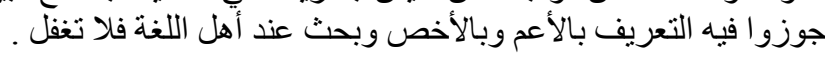

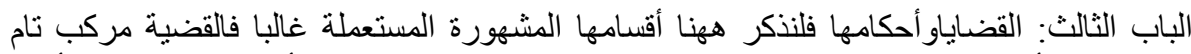

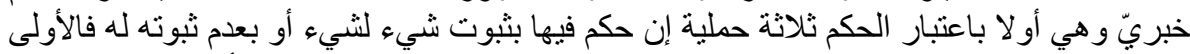

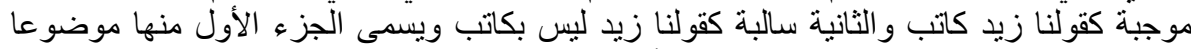

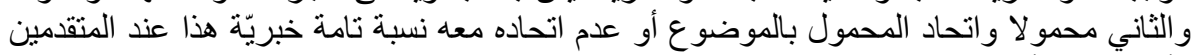

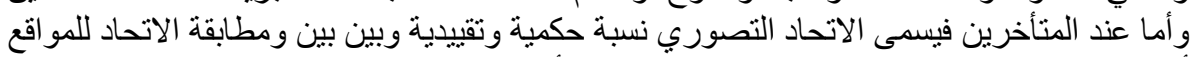

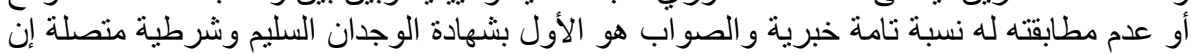

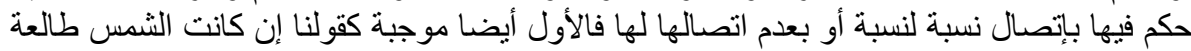

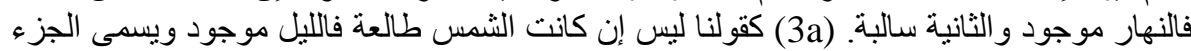

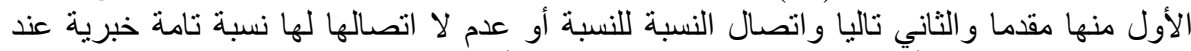

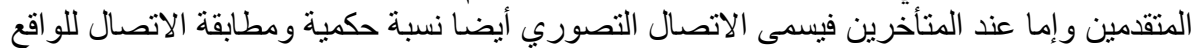

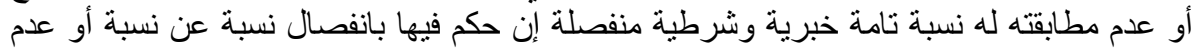

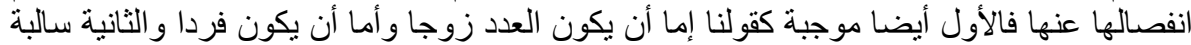

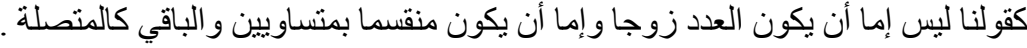

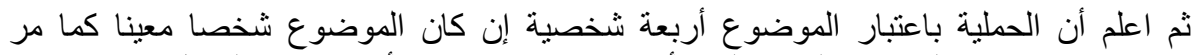

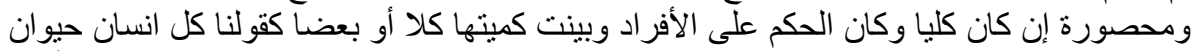

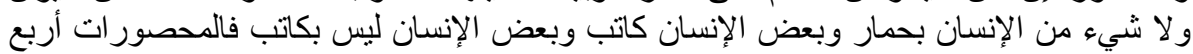

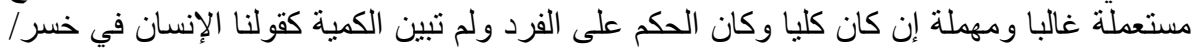

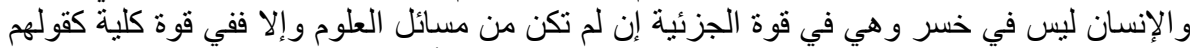

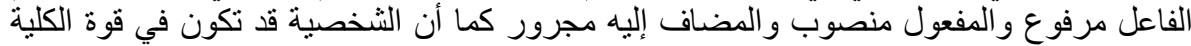
ولذا قالو ا عكس زيد قائم بعض القائم زيد وطبيعية إن كان كليا وكان الحكم عليه فقط نحو الإنسان 


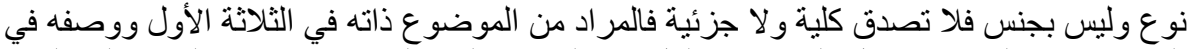

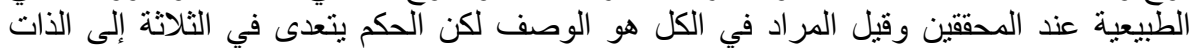

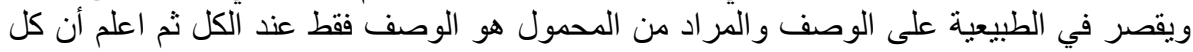

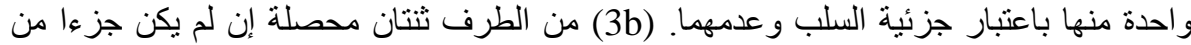

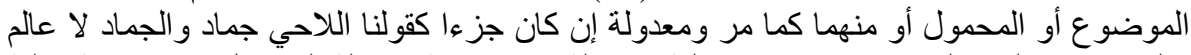

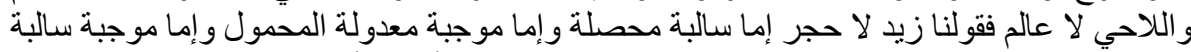

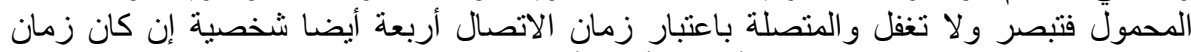

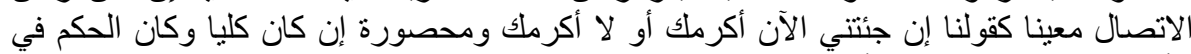

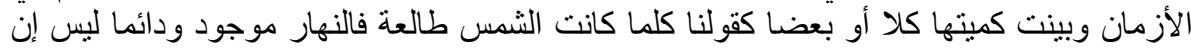

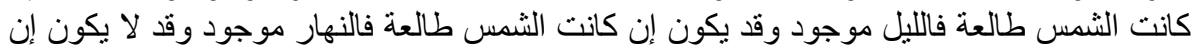

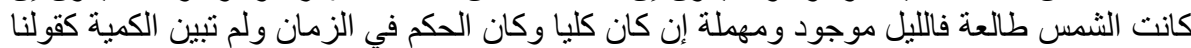

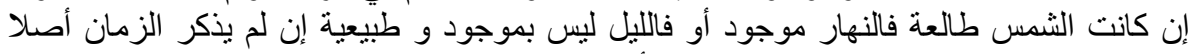

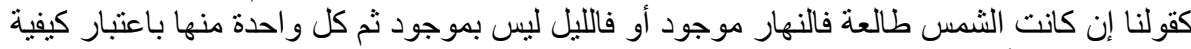

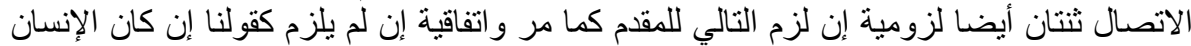

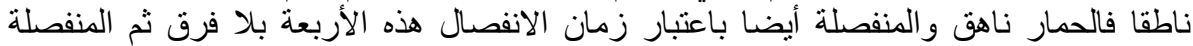

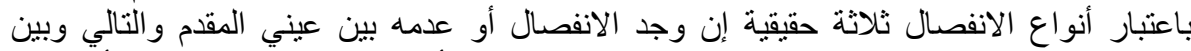

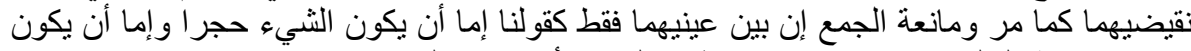

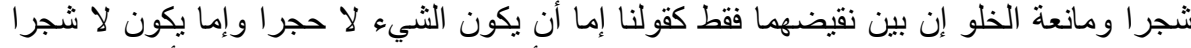

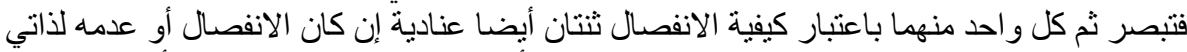

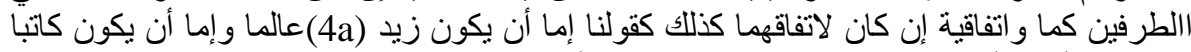

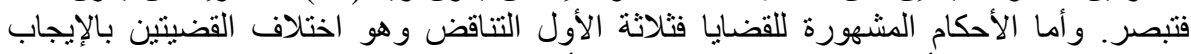

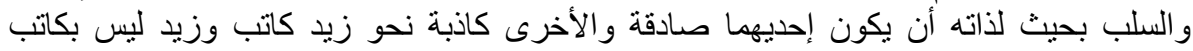

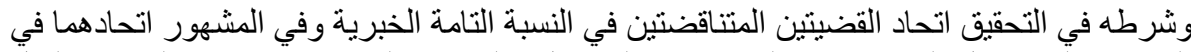

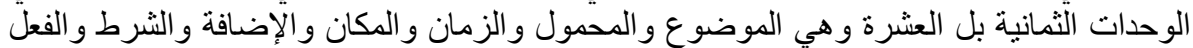

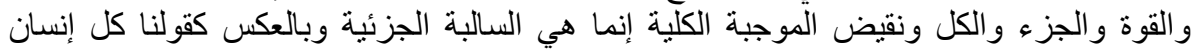

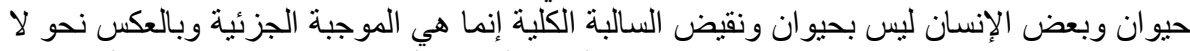

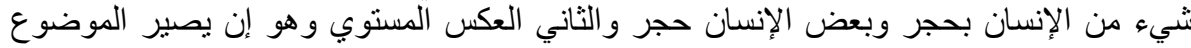

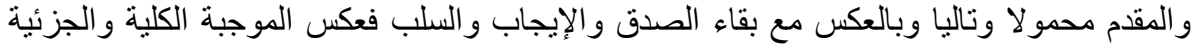

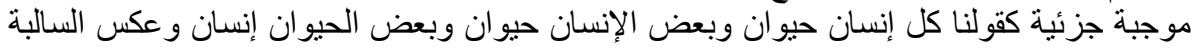

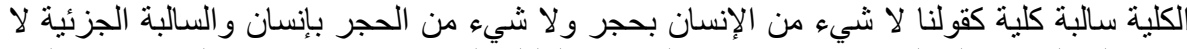

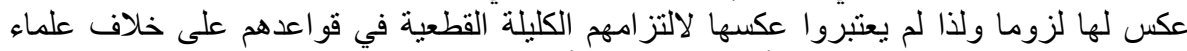

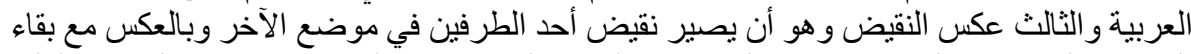

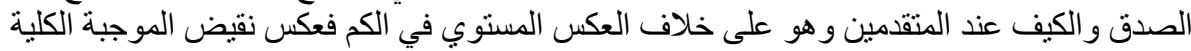

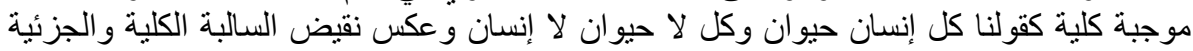

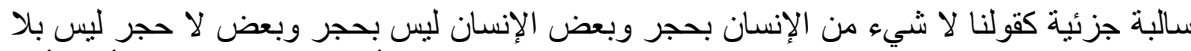

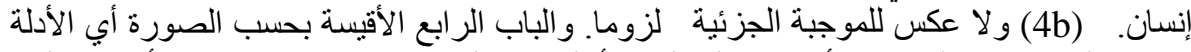

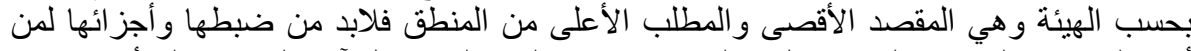

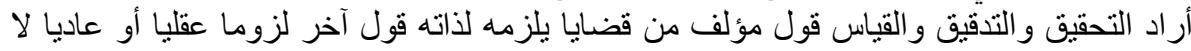

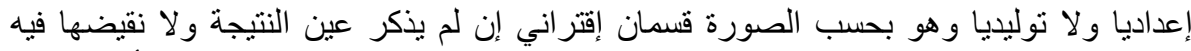
بالفعل كقولنا كل جسم مؤلف وكل مؤلف محدث فكل جسم محدث واستثنائي إن ذكر أحدهما فيه 


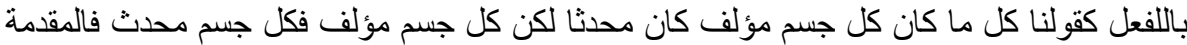

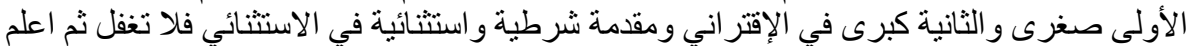

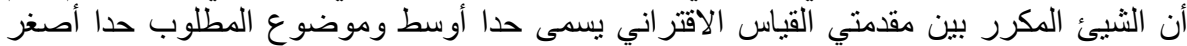

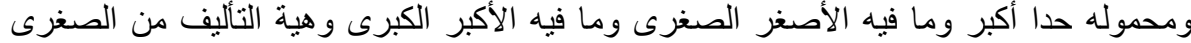
و الكبرى شكلا و الأشكال باعتبار الحد الأوسط أربعة لأن الحد الأوسط إن كان محمو لا في في

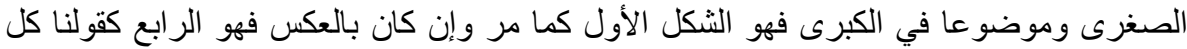

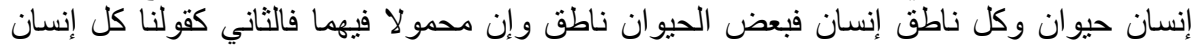

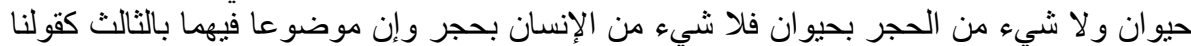

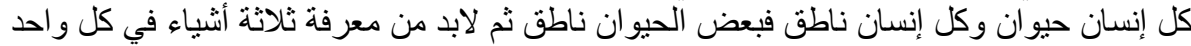

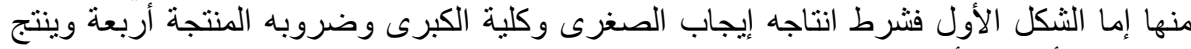

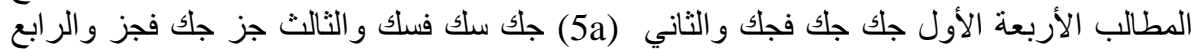

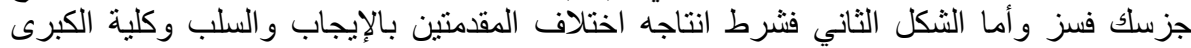

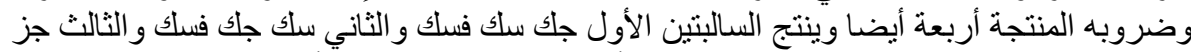

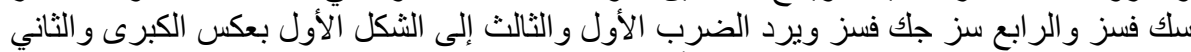

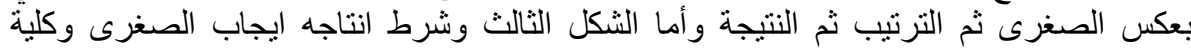

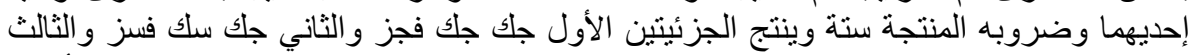

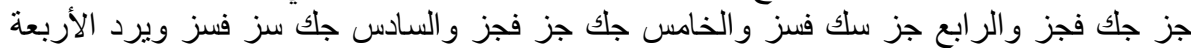

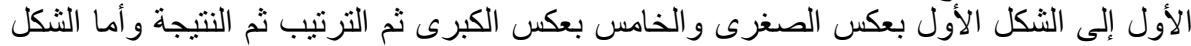

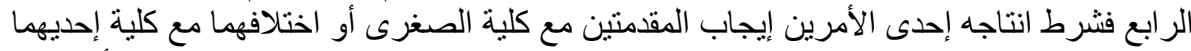

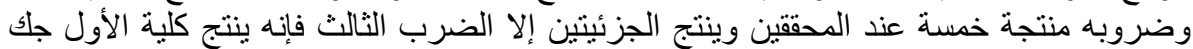

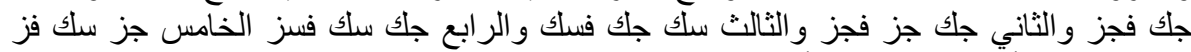

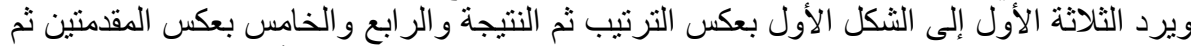

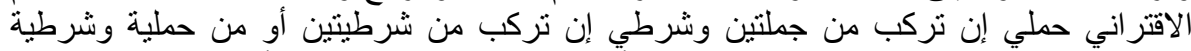

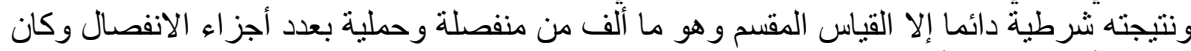

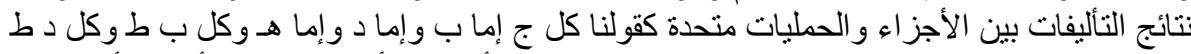

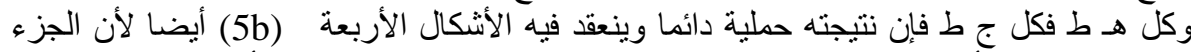

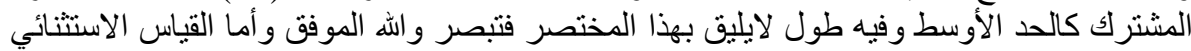

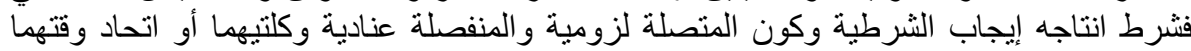

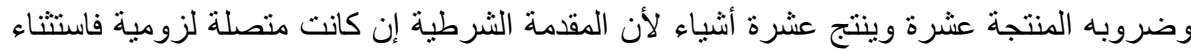

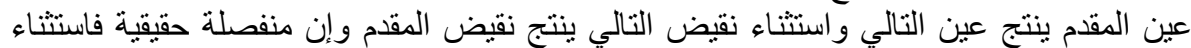

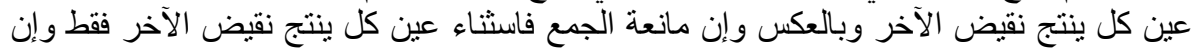

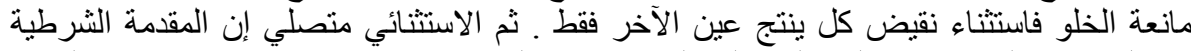

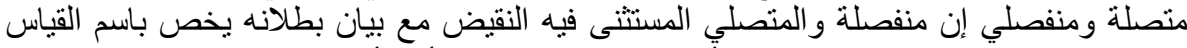

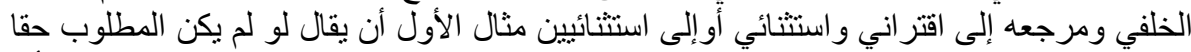

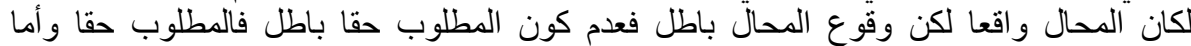

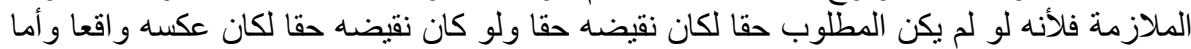

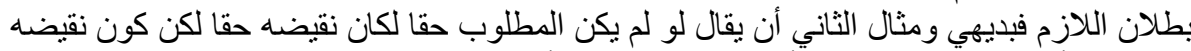

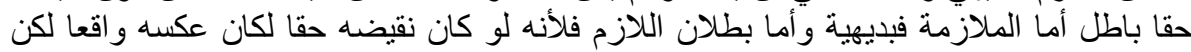

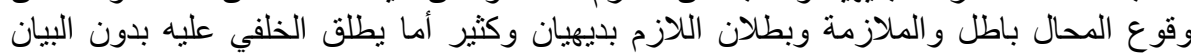

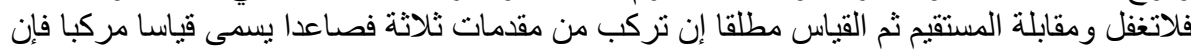


صرح نتيجة المقدمنين وضم ثالثة إلى النتيجة وهكذا إلى أن يحصل المطلوب فموصول النتائج و إلا

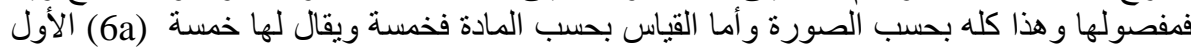

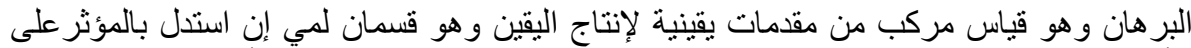

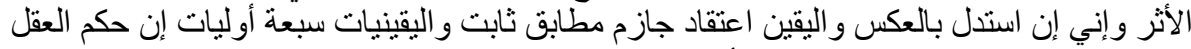

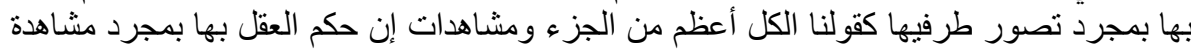

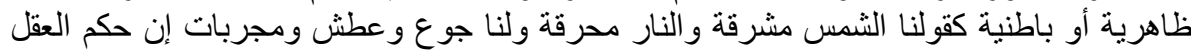

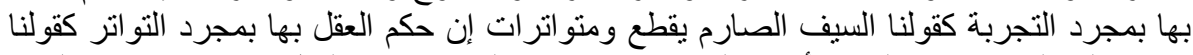

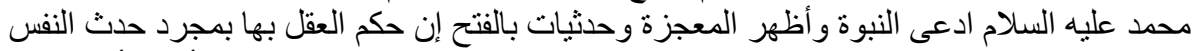

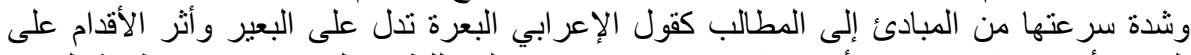

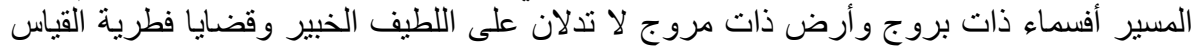

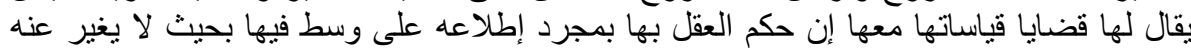

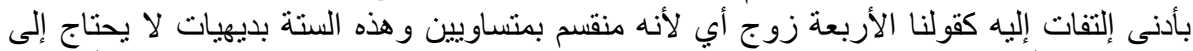

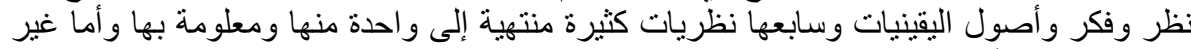

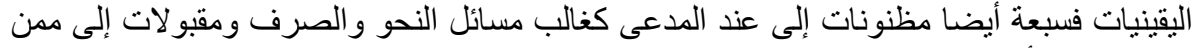

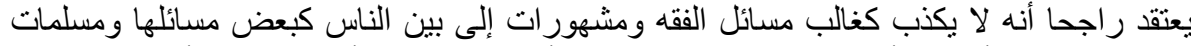

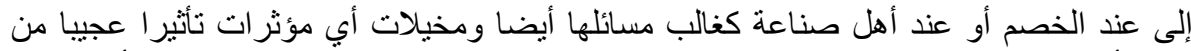

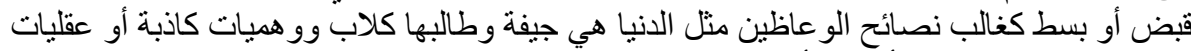

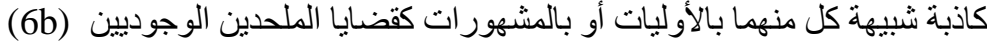

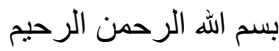

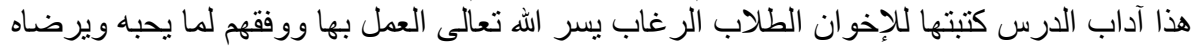

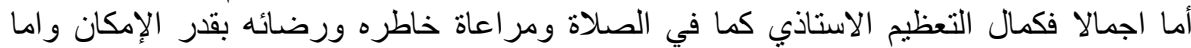

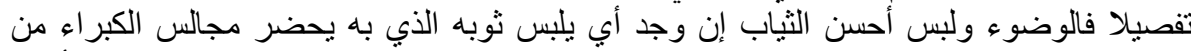

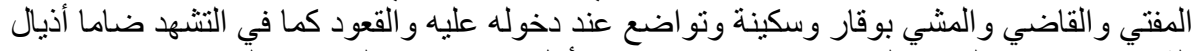

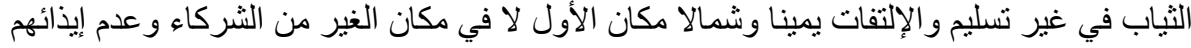

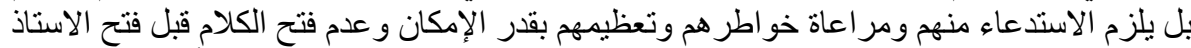

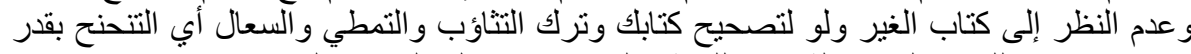

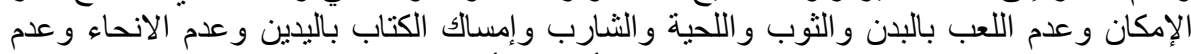

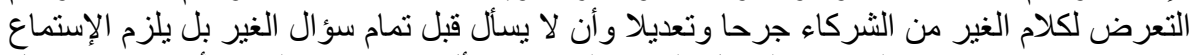

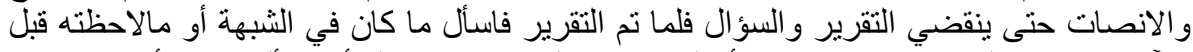

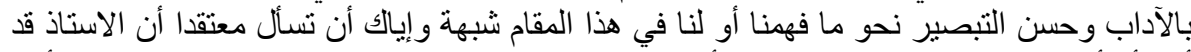

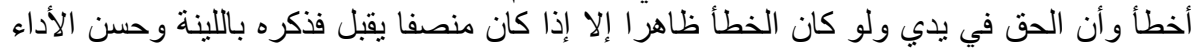

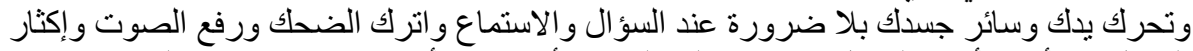

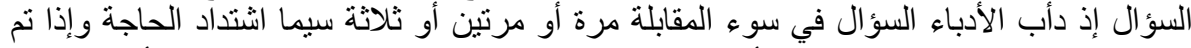

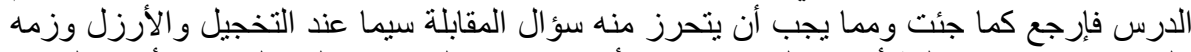

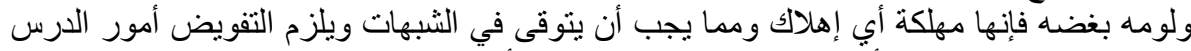

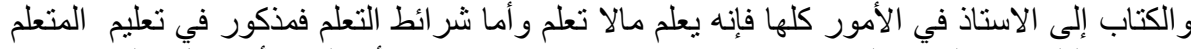

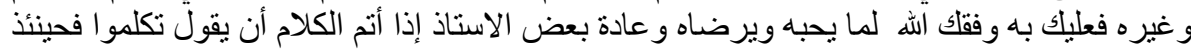

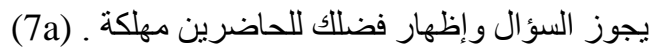

